\title{
Alicja Michalska
}

\section{RYNEK PRACY I SYSTEM EDUKACYJNY. ZARYS PROBLEMATYKI}

\section{Wprowadzenie}

Przejście od etapu edukacji do pracy to ważny i trudny okres w życiu młodego pokolenia Polaków ${ }^{1}$. Wiąże się z nim proces uniezależniania się od rodziców, podejmowania pierwszych samodzielnych decyzji o kluczowym znaczeniu dla przebiegu dalszej kariery itp. Badania pokazują, że praca stanowi istotną wartość dla ponad $62 \%$ młodych ludzi w Polsce ${ }^{2}$. Jej znaczenie zwiększają dodatkowo procesy związane ze starzeniem się ludności, wydłużaniem średniej długości życia, spadkiem urodzeń czy kryzysem ekonomicznym.

Ważną rolę w przebiegu tych procesów mają do odegrania państwo i jego instytucje (Ministerstwo Pracy i Polityki Społecznej, Ministerstwo Edukacji, Ministerstwo Nauki i Szkolnictwa Wyższego), oczekiwania potencjalnych pracodawców i obowiązujące zasady odnoszące się do funkcjonowania rynku pracy, które wyznaczają granice dla podejmowanych działań. Wybierając studia, młodzi ludzie muszą kierować się racjonalnymi przesłankami związanymi z możliwością uzyskania pracy po zakończeniu edukacji. Udział w praktykach, odbywanie stażu, podejmowanie pracy w trakcie studiów niejako z założenia powinny im pozwolić na zdobycie doświadczenia zawodowego, które zwiększy ich konkurencyjność na rynku pracy.

Autorka niniejszej pracy stawia tezę, że absolwenci są grupą defaworyzowaną na rynku pracy, i jednocześnie za cel przyjmuje znalezienie odpowiedzi na pytanie o działania, jakie podejmuje państwo, by zmniejszyć bezrobocie wśród młodzieży. Ponadto sprawdza, w jakim stopniu istniejący system edukacyjny odpowiada na zapotrzebowanie szybko zmieniającego się rynku pracy ${ }^{3}$. Analizie zostały poddane

\footnotetext{
1 Za Eurostatem i GUS-em przyjęto, że młodymi pracownikami są osoby w wieku 15-24 lata.

2 Pierwsze kroki na rynku pracy, raport firmy Deloitte, 2013, http://www.deloitte.com/pl/rynekpracy [dostęp 5.03.2014].

${ }^{3}$ Bezrobocie jest rozumiane jako sytuacja, w której istnieje grupa pracowników zdolna do pracy i gotowa ją podjąć, lecz nieznajdująca możliwości zatrudnienia. R.J. Barro, Makroekonomia, Wydawnictwo Naukowe PWN, Warszawa 1997, s. 276.
} 
zarówno wskaźniki rynkowe dostarczane przez polskie oraz unijne urzędy statystyczne, jak i dokumenty prezentujące strategie rządowe czy europejskie programy na rzecz wsparcia młodych ludzi na rynku pracy.

\section{Bezrobocie i aktywność zawodowa młodzieży w latach 2008-2013}

$\mathrm{Z}$ analizy danych Eurostatu publikowanych w ostatnich latach wynika, że stopa bezrobocia wśród młodych ludzi w całej Unii Europejskiej (UE) jest generalnie wyższa niż w przypadku ogółu populacji. Do momentu wybuchu kryzysu w 2008 r. była ona dwa razy wyższa od ogólnej (dla 27 krajów UE), osiągając najniższą wartość, równą 18,1\%, w pierwszym kwartale $2008 \mathrm{r}^{4}$ Okazało się, że kryzys ekonomiczny zapoczątkowany w trzecim kwartale 2008 r. dotknął młodzież mocniej niż pozostałe grupy wiekowe. Począwszy od 2009 r., różnica pomiędzy młodymi ludźmi a pozostałymi kategoriami bezrobotnych wzrastała, by na koniec 2012 r. osiągnąć 2,5-krotność stopy ogólnej. W maju 2013 r. 23,1\% aktywnych zawodowo osób poniżej 25 roku życia w UE było bezrobotnych, nie licząc zatrudnionych na niepełny etat ${ }^{5}$ (rysunek 1 ).

Rysunek 1. Stopa bezrobocia młodych w krajach Unii Europejskiej (EU-28 oraz EA-17) styczeń 2003-styczeń 2013 (w \%)

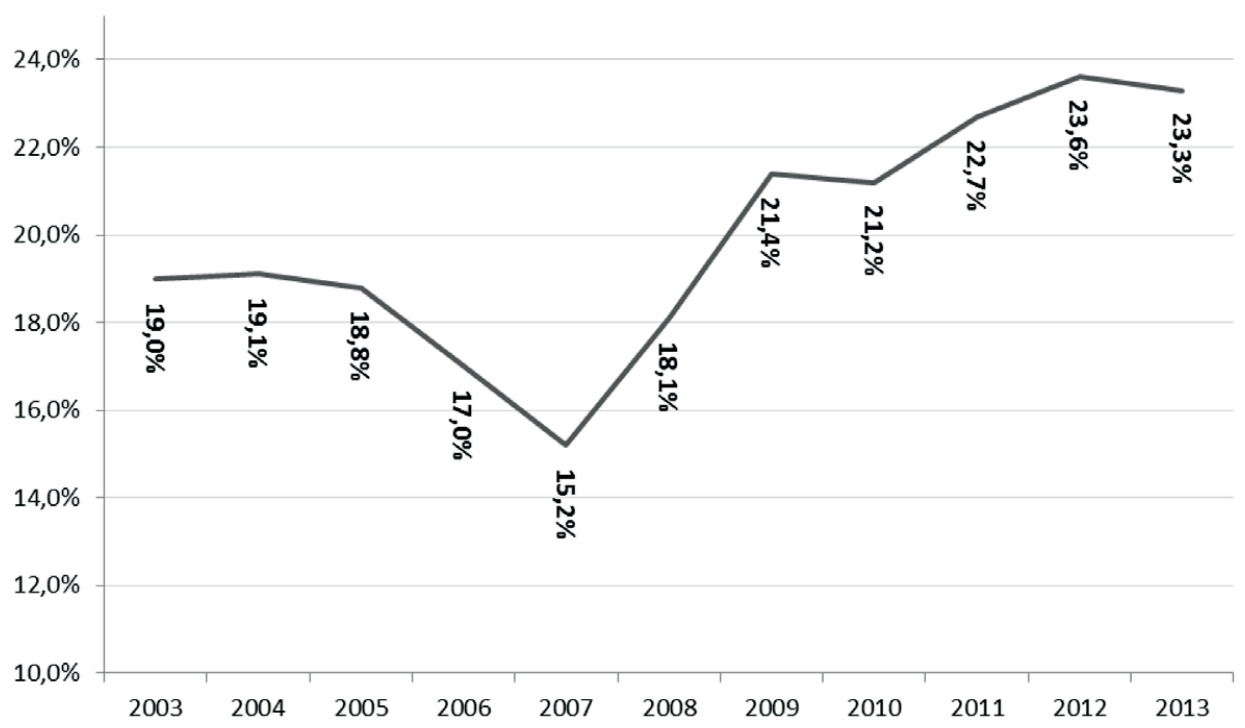

Źródło: Eurostat, http://epp.eurostat.ec.europa.eu/statistics_explained/index.php/Unemployment_statistics [dostęp 4.03.2014].

\footnotetext{
${ }^{4}$ Unemployment Statistics (2013). Youth unemployment figures, Eurostat, s. 2010-2012.

${ }^{5}$ Ibidem.
} 
Jak możemy zobaczyć, szczególnie niepokojącą kategorię na rynku pracy w całej UE, generującą znaczne koszty społeczne, stanowią osoby młode, zaliczane do tzw. NEET (ang. not in employment, education, training), czyli grupy nieuczących się, niepracujących i niedokształcających się. W UE w 2010 r. do kategorii NEET należało 16,5\% osób w grupie 18-24 lata oraz 19,7\% w grupie wiekowej 25-29 lat. Powszechną tendencją w państwach UE jest wzrost odsetka kategorii NEET wśród młodych ludzi po przekroczeniu 25 roku życia, co wskazuje, że niezależnie od kraju przechodzenie z okresu późnej edukacji do zatrudnienia napotyka na poważne utrudnienia. Dla dużej grupy młodych osób oznacza to bierność w obszarze zarówno podejmowania pracy, podnoszenia kwalifikacji, jak i kontynuowania edukacji ${ }^{6}$. Warto zaznaczyć, że NEETs podlegają szczególnie wysokiemu ryzyku społecznej ekskluzji. Wynika to głównie z faktu pozostawania poza układem instytucji, które pozwalają im na nabywanie i zwiększanie niezbędnych na rynku pracy kwalifikacji i umiejętności, a także innych kompetencji - zarówno społecznych, jak i obywatelskich.

W Polsce w drugiej połowie 2012 r. przybyło ok. 0,5 mln wszystkich bezrobotnych, co wpłynęło na wzrost stopy bezrobocia o 2,9 punktu procentowego. Odnosząc te dane do badanej grupy osób w wieku 15-24 lata, można stwierdzić, że stopa bezrobocia dla tej grupy w Polsce w 2012 r. przekroczyła 27\% ${ }^{7}$. Według danych GUS odsetek młodych bezrobotnych w stosunku do grupy aktywnych zawodowo wynosi $27,4 \%^{8}$. Są to dane zbieżne $z$ informacjami podawanymi przez Eurostat $(27,5 \%)$.

Definiując sytuację osób młodych na rynku pracy, można stosować dwa wskaźniki: stopę bezrobocia (przywoływaną powyżej) oraz wskaźnik bezrobocia. Stopa bezrobocia opisuje liczbę osób bezrobotnych (w wieku 15-24 lata) w stosunku do udziału osób aktywnych zawodowo, a wskaźnik bezrobocia jako mianownik stosuje całkowitą populację młodych osób w tym samym wieku. Okazuje się, że w Polsce w 2012 r. stopa bezrobocia wynosiła 27,5\%, a wskaźnik bezrobocia 8,9\% (wobec odpowiednio $23 \%$ i 9,7\% w UE). Różnicę pomiędzy oboma wskaźnikami możemy wyjaśnić wydłużaniem okresu pobierania nauki przez młode pokolenie Polaków. Jego celem jest uniknięcie okresu pozostawania bez pracy ${ }^{9}$. Zdobycie wyższego wykształcenia staje się w tej sytuacji zachowaniem jak najbardziej racjonalnym.

Nieco inne wartości znajdziemy w Bilansie Kapitału Ludzkiego (BKL) z 2013 r. Według zawartych w nim informacji $20 \%$ ogółu bezrobotnych stanowią absolwenci

${ }^{6}$ M. Pańkow, Młodzi na rynku pracy, raport Instytutu Spraw Obywatelskich oraz Fundacji PZU, Warszawa 2012, s. 14-15.

7 Bilans Kapitału Ludzkiego 2013. Młodość czy doświadczenie. Kapitał ludzki w Polsce, 2013, http://bkl.parp.gov. pl/system/files/Downloads/20121128143313/BKL_Raport_2013_int_m.pdf?1364281897 [dostęp 5.03.2014].

${ }_{8}^{8}$ Monitoring rynku pracy. Kwartalna informacja o aktywności ekonomicznej ludności (2013), GUS, s. 9, http:// www.stat.gov.pl/cps/rde/xbcr/gus/PW_kwartalna_inf_o_rynku_pracy_I_kw_2013.pdf [dostęp 2.03.2014].

9 P. Arak, Wejście młodych ludzi na rynek pracy. Oczekiwania i możliwości realizacji, „Polityka Społeczna” 2013, nr 10, s. 5-11. 
do 30 roku życia. Bez pracy częściej pozostają kobiety, a najwyższa stopa bezrobocia dotyczy młodych mieszkańców wsi i małych miasteczek (do 10 tys. mieszkańców), najniższa zaś - dużych miast.

W ciągu ostatnich 5 lat na polski rynek pracy weszło $2,5 \mathrm{mln}$ absolwentów ${ }^{10}$. Największą grupę stanowili absolwenci szkół średnich (40\%) i wyższych (38\%), $14 \%$ - absolwenci szkół zawodowych, a 7\% - osoby z wykształceniem podstawowym. Dynamikę zmian ilustruje rysunek 2.

\section{Rysunek 2. Odsetek absolwentów z lat 2008-2012 w podziale ze względu na uzyskane wykształcenie}

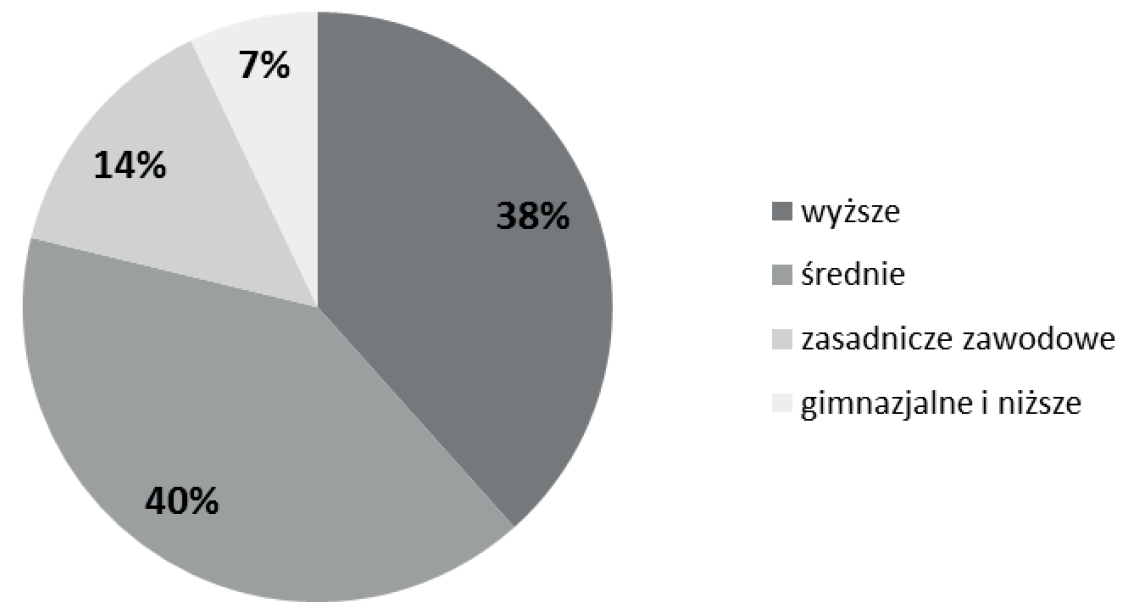

Źródło: Bilans Kapitału Ludzkiego 2013. Młodość czy doświadczenie. Kapitał ludzki w Polsce, 2013, http://bkl. parp.gov.pl/system/files/Downloads/20121128143313/BKL_Raport_2013_int_m.pdf?1364281897 [dostęp 5.03.2014].

Analizując zawarte na wykresie informacje, można zauważyć, że mimo generalnie trudnej sytuacji młodych ludzi posiadane wykształcenie w znaczący sposób wpływa na ich perspektywy zawodowe. W świetle statystyk dotyczących rynku pracy najgorzej wypadają absolwenci szkół zawodowych - stopa bezrobocia w tej grupie osiąga poziom nawet 19,3\% (2012 r.), stosunkowo lepiej wypadają absolwenci uczelni technicznych i liceów (odpowiednio 14\% oraz 16,2\%), najlepiej - co w tej sytuacji nie powinno dziwić - absolwenci studiów inżynierskich i magisterskich $(12,3 \%$ oraz $10,3 \%)$.

${ }^{10}$ Absolwent - osoba, która ukończyła klasę programowo najwyższą w danym typie szkoły i otrzymała świadectwo ukończenia tej szkoły (dotyczy absolwentów w szkołach objętych systemem oświaty). Absolwent szkoły wyższej to osoba, która uzyskała dyplom stwierdzający ukończenie studiów wyższych i - po obronie pracy - uzyskała tytuł zawodowy magistra (po studiach magisterskich jednolitych lub drugiego stopnia/ uzupełniających), inżyniera lub licencjata (po studiach pierwszego stopnia/zawodowych) - definicja GUS, http://www.stat.gov.pl/gus/definicje_PLK_HTML.htm?id=POJ-1.htm [dostęp 5.03.2014]. 
Tabela 1. Aktywność zawodowa absolwentów szkół ponadgimnazjalnych oraz szkół wyższych $(\mathbf{w} \%)$

\begin{tabular}{|c|c|c|c|}
\hline Profil wykształcenia & Pracujący & Bezrobotni & Nieaktywni \\
\hline Ogólne (liceum) & 60,90 & 16,20 & 22,90 \\
\hline Techniczne (średnie po technikum) & 74,40 & 14 & 11,07 \\
\hline Robotnicze (ZSZ) & 68,30 & 19,30 & 12,04 \\
\hline Usługowe (ZSZ) & 52,30 & 18,30 & 29,30 \\
\hline Licencjat & 63,80 & 16,90 & 19,30 \\
\hline Inżynier & 76,50 & 12,30 & 11,10 \\
\hline Magister & 80,70 & 10,30 & 9 \\
\hline Magister inżynier & 85,03 & 10,10 & 4,60 \\
\hline
\end{tabular}

Źródło: Bilans Kapitału Ludzkiego 2013. Młodość czy doświadczenie. Kapitał ludzki w Polsce, 2013, http://bkl. parp.gov.pl/system/files/Downloads/20121128143313/BKL_Raport_2013_int_m.pdf?1364281897 [dostęp 5.03.2014].

Gdy porównamy okres poszukiwania pracy przez przedstawicieli poszczególnych grup (rysunek 3), możemy zauważyć występowanie podobnej zależności - im wyższe wykształcenie miała dana osoba, tym szybciej znajdowała pracę. Najwyższy wskaźnik zatrudnienia oraz najniższą stopę bezrobocia odnotowano wśród absolwentów studiów medycznych oraz inżynieryjno-technicznych - 90\%. Uwzględniając regiony, należy stwierdzić, że najniższe wskaźniki bezrobocia wśród absolwentów uczelni wyższych $\mathrm{z}$ ostatnich 5 lat zaobserwowano w województwie dolnośląskim i wielkopolskim (18\%). Wskaźniki zatrudnienia absolwentów sięgały tam nawet 70\%.

\section{Rysunek 3. Okres poszukiwania pracy przez bezrobotnych według wykształcenia (w miesiącach)}

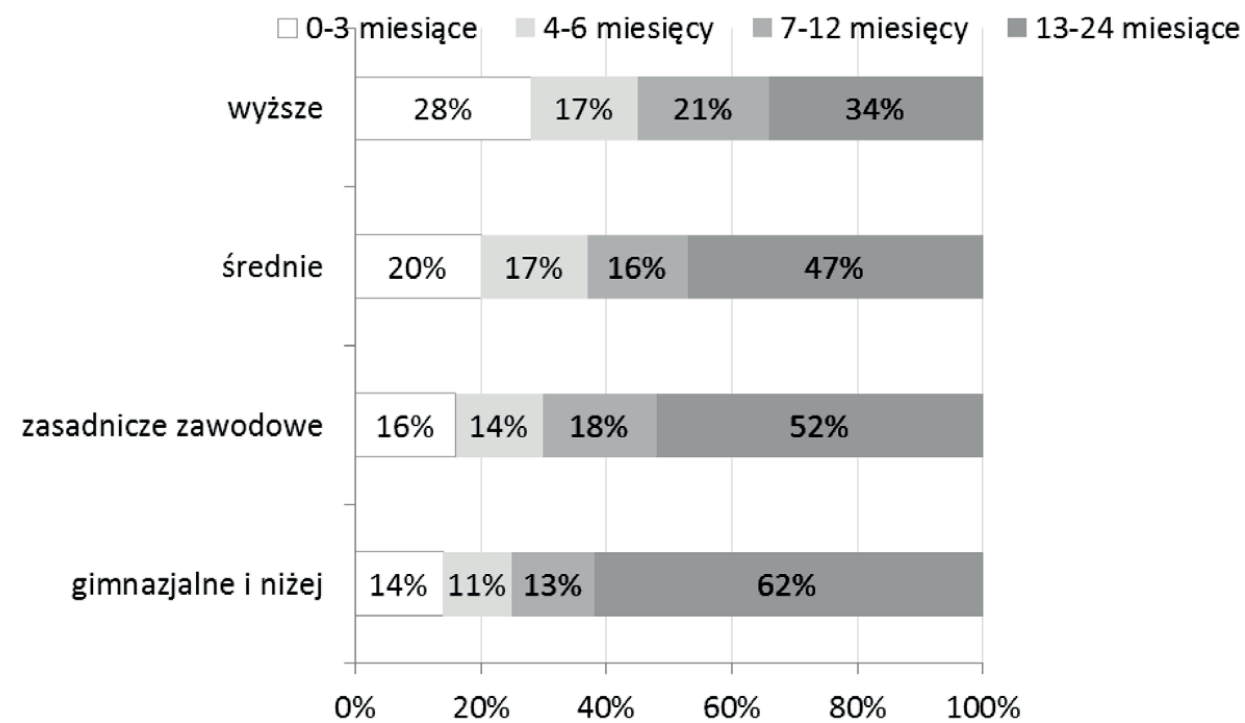

Źródło: Bilans Kapitału Ludzkiego 2013. Młodość czy doświadczenie. Kapitał ludzki w Polsce, 2013, http://bkl. parp.gov.pl/system/files/Downloads/20121128143313/BKL_Raport_2013_int_m.pdf?1364281897 [dostęp 5.03.2014]. 
Analizując statystyki dotyczące młodych ludzi na rynku pracy w Polsce, można zauważyć, że co czwarty bezrobotny pozostaje bez zatrudnienia ponad 12 miesięcy od momentu zarejestrowania się w urzędzie pracy ${ }^{11}$. Jest to szczególnie negatywne zjawisko, ponieważ dotyczy osób, które dopiero wkraczają na rynek pracy ${ }^{12}$. Wpływa to na obniżenie motywacji związanych z poszukiwaniem zatrudnienia, co przejawia się w takich zachowaniach, jak:

- utrata umiejętności lub brak możliwości zdobycia doświadczenia,

- obniżanie morale pracy oraz aspiracji edukacyjnych,

- marginalizacja bezrobotnego i jego rodziny, eliminacja ze środowiska społecznego, rozwój patologii,

- frustracja, obojętność, zaburzenia nerwowe czy choroby psychiczne, prowadzące niekiedy do samobójstw ${ }^{13}$.

Oprócz indywidualnych czy społecznych kosztów bezrobocia, należy wymienić także koszty fiskalne, wpływające na spadek dochodów budżetu państwa z podatków osobistych, czy te związane z obniżeniem wydatków konsumpcyjnych osób bezrobotnych. Zjawiskom tym towarzyszy wzrost wydatków państwa przeznaczanych na aktywizację bezrobotnych, z czym należy wiązać także wysokość wypłacanych zasiłków ${ }^{14}$.

\section{Rynek pracy w Polsce. Wybrane zagadnienia}

Za Międzynarodową Organizacją Pracy (MOP) możemy wyróżnić kilka barier mających wpływ na sytuację młodych ludzi na rynku pracy. Należą do nich m.in.:

1. Niedopasowanie umiejętności poszukiwanych przez pracodawców do posiadanych przez potencjalnych pracowników. Jest ono szczególnie widoczne u osób z wykształceniem technicznym ${ }^{15}$.

2. Dyskryminujące praktyki pracodawców stosowane wobec młodych pracowników, np.: gorsze oferty pracy, umowy śmieciowe lub szybsze zwolnienia ${ }^{16}$.

\footnotetext{
${ }^{11}$ Bilans Kapitału Ludzkiego 2013..., op.cit.

${ }_{12}$ Młodzi na rynku pracy. Działania na rzecz zmniejszenia bezrobocia młodzieży, program Ministerstwa Pracy i Polityki Społecznej, Warszawa 2012, http://www.mpips.gov.pl/aktualnosci-wszystkie/ art,5543,5779,program-mlodzi-na-rynku-pracy.html [dostęp 2.03.2014].

${ }^{13}$ A. Lipka, Indywidualne koszty bezrobocia. Próba klasyfikacji, „Polityka Społeczna” 1992, nr 3.

14 D. Kotlorz, Bezrobocie, w: Polityka społeczna. Wybrane zagadnienia, red. L. Frąckiewicz, Wydawnictwo Akademii Ekonomicznej, Katowice 1994, s. 102.

${ }_{15}$ P. Arak, op.cit., s. 5-11.

16 Ibidem.
} 
3. Źle działające systemy sygnalizowania nieprawidłowości w relacjach pracownik-rynek pracy. W konsekwencji, młodzi ludzie podejmują pracę nieadekwatną do swoich kwalifikacji, co sprawia, że już na początku zawodowej drogi są źle alokowani na rynku pracy.

4. Problemy związane z tworzeniem nowych miejsc pracy - zakładaniem własnej firmy. Najbardziej dotkliwe okazują się problemy finansowe; osoby dotknięte nimi nie są postrzegane jako wiarygodni klienci banków, a na wsparcie rodziny często nie mogą liczyć17.

Młody człowiek, chcąc odnaleźć się w nowej sytuacji, musi mieć świadomość, że rynkiem pracy rządzi mechanizm wyrównywania popytu na pracę i jej podaży; jeszcze szybciej zmianom ulega jednak struktura rynku. Wyżej zatem będą oceniane umiejętności i możliwości wykonywania pracy o najbardziej poszukiwanych i specyficznych parametrach - czyli te rzadko spotykane. Decydują o tym zarówno kwalifikacje nabyte (wykształcenie), jak i posiadane umiejętności praktyczne. W ekonomii przyjmuje się, że w warunkach gospodarki rynkowej lepiej wynagradzani są pracownicy, którzy przez wysiłek edukacyjny osiągają wyższe poziomy kwalifikacyjne. Ta zasada sprawdza się także wśród pracodawców ${ }^{18}$.

Zobaczmy zatem, jakie są oczekiwania potencjalnych pracodawców formułowane wobec młodych pracowników, wchodzących dopiero na rynek pracy.

\subsection{Oczekiwania pracodawców}

Pracodawcy oferujący zatrudnienie młodym ludziom mają najczęściej sprecyzowane oczekiwania co do typu ich wykształcenia, często także doświadczenia zawodowego. Połowa przebadanych w BKL pracodawców, którzy deklarują zatrudnianie początkujących pracowników, jest przekonana, że będzie musiała ich doszkalać. Co więcej, 85\% respondentów poszukuje pracowników na stanowiska już funkcjonujące w firmie, a nie nowo utworzone. Oprócz oczekiwań dotyczących wykształcenia czy płci, absolwentom - także na początkowym etapie - stawia się wymagania związane z doświadczeniem. Dla większości pracodawców zadowalający jest przynajmniej półroczny staż pracy.

Najczęściej poszukiwanymi kompetencjami są głównie tzw. umiejętności miękkie, tj.: odpowiedzialność, uczciwość, wiarygodność, dyscyplina pracy, komunikatywność, kultura osobista czy dbanie o wizerunek własny. Istotne okazują się także:

\footnotetext{
17 M. Boni, Młodzi 2011, Kancelaria Prezesa Rady Ministrów, Warszawa 2011, s. 133-134.

18 W. Kozek, Rynek pracy. Perspektywa instytucjonalna, Wydawnictwa Uniwersytetu Warszawskiego, Warszawa 2013, s. 201-202.
} 
dyspozycyjność, kreatywność i chęć do pracy. Z coraz większą liczbą stanowisk wiąże się wymaganie znajomości języków obcych (głównie języka angielskiego). Natomiast podkreślane przez pracodawców braki w wiedzy kierunkowej absolwentów odnoszą się przede wszystkim do braku doświadczenia praktycznego oraz kompetencji miękkich, traktowanych jako efekt niedopasowania systemu edukacyjnego do wymagań rynku pracy ${ }^{19}$. Od wielu lat $\mathrm{w}$ podstawie programowej szkół wyższych pomija się znaczenie praktycznego nabywania umiejętności, a często jedyną możliwością zdobycia przez studentów doświadczenia zawodowego są bezpłatne staże odbywane po zajęciach akademickich czy w czasie wakacji.

Szczegółowe badania nad wymaganiami pracodawców wobec nowych pracowników przeprowadzono w 2012 r. w ramach Programu Operacyjnego Innowacyjna Gospodarka, dla szkół wyższych z regionu Mazowsza ${ }^{20}$. Pokazują one, że najważniejszymi kompetencjami poszukiwanymi u nowych pracowników są samodzielność oraz wiedza kierunkowa (ponad 50\% badanych). Kolejne pozycje zajmują umiejętności analitycznego myślenia (48\%) oraz używania narzędzi informatycznych (41\%). Pracodawcy oczekują także od absolwentów umiejętności pracy zespołowej (40\%) oraz rozwiązywania problemów (blisko $38 \%$ firm). Okazuje się także, że większą szansę na znalezienie pracy na coraz bardziej konkurencyjnym rynku mają ci, którzy mają umiejętności zawodowe potwierdzone dodatkowymi certyfikatami. Coraz częściej też poszukiwani są młodzi ludzie wykazujący się kreatywnością (36\% wskazań).

Jak możemy zauważyć, pracodawcy najbardziej cenią u swoich pracowników wiedzę ogólną i ogólnozawodową (43\% odpowiedzi) oraz umiejętności posługiwania się narzędziami informatycznymi (41\%). Krytycznie natomiast oceniają radzenie sobie ze stresem, kierowanie zespołem czy umiejętności komunikacyjne.

Wydaje się zatem, że przewaga młodych pracowników nad starszymi i bardziej doświadczonymi odnosi się głównie do umiejętności posługiwania się nowymi technologiami, a nie - do wiedzy specjalistycznej ${ }^{21}$.

\subsection{Formy i warunki zatrudniania}

Negatywnie należy także odnieść się do form i warunków zatrudniania młodych ludzi. Chodzi o tzw. umowy terminowe oraz kontrakty śmieciowe, czyli umowy cywilnoprawne. Ministerstwo Pracy i Polityki Społecznej wskazuje na ich

19 Bilans Kapitału Ludzkiego 2013..., op.cit., s. 127.

${ }^{20}$ Diagnoza zapotrzebowania na kwalifikacje i kompetencje absolwentów szkót wyższych Mazowsza wchodzacych na rynek pracy. Raport z badania, Warszawa 2012, s. 52, http://www.akademickiemazowsze2030. pl/data/file/222.pdf [dostęp 20.03.2014].

${ }^{21}$ Ibidem, s. 52-54. 
„zbawienny” wpływ na wzrost zatrudnienia. W Polsce tego typu umowy stanowią już prawie $27 \%$ wszystkich zawieranych umów (2013 r.). Jest to najwyższy wynik wśród krajów OECD, gdzie średnia dla tego typu rozwiązań to ok. $12 \%{ }^{22}$.

W kontekście zatrudniania młodych osób stosowanie elastycznych form zatrudnienia z perspektywy pracodawcy wydaje się istotnym udogodnieniem, dającym możliwość zweryfikowania umiejętności pracownika czy obniżki kosztów wynikających z zatrudnienia niewłaściwej osoby. To w pewnym sensie również kompensacja wyższych nakładów poniesionych wcześniej na inwestycje w „młody” kapitał ludzki, wymagający dokształcenia, oraz zabezpieczenie przed naturalną skłonnością młodych osób poniżej 30 roku życia do częstych zmian pracy.

Z kolei dla młodych pracowników elastyczne formy zatrudnienia $\mathrm{z}$ niepełnym wymiarem czasu pracy oznaczają - z jednej strony - możliwość pogodzenia nauki z pracą zarobkową, z drugiej jednak - ryzyko niskich dochodów czy też „wpadnięcia w pułapkę" umów terminowych. Momentem, w którym ta forma zatrudnienia najbardziej zaczyna doskwierać, jest sytuacja, w której młody człowiek potrzebuje usamodzielnienia się czy podejmuje decyzję o założeniu rodziny. Ustawodawcy stoją dziś przed takimi uregulowaniami rynku pracy, które pozwalają zachować konkurencyjność przedsiębiorstw przez uelastycznienie czasu i miejsca pracy pracowników, a także zadbać o bezpieczeństwo socjalne pracowników i ich rodzin ${ }^{23}$.

\subsection{Migracje}

Oddzielny problem stanowią migracje młodych ludzi za granicę. Zarówno dawne (przedakcesyjne), jak i obecne wyjazdy w zdecydowanej większości (ok. 90\%) były i są związane z poszukiwaniem pracy. Wśród czynników, które skłaniały do wyjazdu za granicę, znajdują się: niskie płace, wysokie koszty pracy, finansowe i formalne bariery w zakładaniu własnych firm oraz atmosfera życia publicznego ${ }^{24}$.

Główny strumień migrujących stanowią osoby w wieku 18-30 lat. Dane brytyjskiego Home Office podają, że wśród osób, które wyjechały z Polski po 2004 r. do Wielkiej Brytanii, $83 \%$ było poniżej 34 roku życia, a niemal połowa nie miała 24 lat. Są to osoby urodzone w latach 1980-1986, czyli roczniki wyżu demogra-

22 Employment Outlook 2013, OECD, www.oecd.org/els/emp/oecdemploymentoutlook.htm [dostęp 4.04.2014].

23 J. Gardawski, L. Gilejko, J. Siewierski, R. Towalski, Socjologia gospodarki, Difin, Warszawa 2006, s. 105.

${ }^{24}$ Rynek pracy w Polsce w poczatkach XXI wieku. Wybrane zagadnienia, red. U. Klonowska, Instytut Badań Rynku, Konsumpcji i Koniunktur, Warszawa 2012, s. 13. 
ficznego, których przedstawiciele, wchodząc na rynek pracy, spotkali się z brakiem nowych miejsc zatrudnienia ${ }^{25}$.

W latach 2006-2007 37\% emigrantów legitymowało się wykształceniem średnim, jedynie $20 \%$ - wyższym. Rok później osoby mające wykształcenie wyższe stanowiły już 26\% emigrantów zarobkowych; warto też zwrócić uwagę na fakt, że jedynie co dziesiąty wyjeżdżający z wyższym wykształceniem wykonuje za granicą pracę zgodną ze swoimi kwalifikacjami, praca pozostałych jest poniżej tych kwalifikacji. Patrząc na emigracje zarobkowe z tej perspektywy, należy stwierdzić, że nie dziwią stwierdzenia „drenażu mózgów” (ang. brain drain) czy ich marnotrawienia (ang. waste brain) ${ }^{26}$.

Migracje za granicę stają się w globalnym i globalizującym się świecie coraz bardziej powszechne. W okresie największego naporu roczników wyżu demograficznego na rynek pracy służyły one rozładowywaniu napięcia związanego z wysokim bezrobociem, stanowiąc rodzaj wentyla bezpieczeństwa dla niewydolnego systemu. Obecnie perspektywa licznych migracji ludzi młodych nie jest korzystna, zwłaszcza że Polska nie jest miejscem, które w miejsce emigrantów przyciąga imigrantów $\mathrm{z}$ innych krajów, i to równie dobrze wykształconych.

\section{Rozwiązania unijne na rzecz ograniczania bezrobocia wśród młodzieży}

Unia Europejska niemal od początku swojego istnienia starała się wypracować wspólne dla wszystkich krajów członkowskich założenia i narzędzia odnoszące się do rynku pracy ${ }^{27}$. Jednym z nich jest tzw. flexicurity - model elastycznego bezpieczeństwa na rynku pracy. Holenderscy badacze T. Wilthagen oraz F. Tros definiują flexicurity jako poziom ochrony pracy, dochodu, zatrudnienia i gwarancji pogodzenia aktywności zawodowej z życiem rodzinnym, ułatwiający ścieżkę rozwoju na rynku pracy i zdobywanie doświadczeń zawodowych przez pracowników o relatywnie gorszej pozycji startowej. Umożliwia im tym samym dostęp do pracy dobrej jakości oraz społeczną inkluzję, zapewniając przy tym poziom elastyczności funkcjonalnej

25 Accession Monitoring Report, May 2004-September 2008, Home Office, UK Border Agency 2008, s. 10-11, http://webarchive.nationalarchives.gov.uk/20100422120657/http://www.ukba.homeoffice.gov. $\mathrm{uk} /$ sitecontent/documents/aboutus/reports/accession_monitoring_report/report17/may04sept08.pdf?vie$\mathrm{w}=$ Binary [dostęp 5.03.2014].

26 M. Boni, op.cit., s. 77-80.

27 J.M. Szaban, Rynek pracy w Polsce i w Unii Europejskiej, Difin, Warszawa 2013, s. 61-62. 
oraz płacowej. To z kolei ułatwia rynkom pracy odpowiednie dostosowanie się do zmieniających się uwarunkowań, aby utrzymać oraz zwiększyć konkurencyjność i produktywność ${ }^{28}$.

Flexicurity oznacza próbę połączenia elastyczności zatrudniania z możliwie najlepszym zapewnieniem pracownikom niezbędnego bezpieczeństwa socjalnego. Co więcej, model ten zapewnia elastyczność zarówno pracownikom, jak i pracodawcom oraz zmniejsza barierę pomiędzy osobami aktywnymi i biernymi zawodowo oraz między bezrobotnymi a zatrudnionymi ${ }^{29}$.

Głównymi wytycznymi do rozwoju polityki flexicurity, zawartymi w komunikacie Komisji Europejskiej z 2007 r., są cztery ścieżki:

1. Elastyczności i przewidywalności warunków zawieranych umów.

2. Wdrażania kompleksowych strategii uczenia się przez całe życie.

3. Promowania aktywnej polityki rynku pracy, służącej skracaniu okresów pozostawania bez zatrudnienia.

4. Opracowywania nowoczesnych systemów zabezpieczenia społecznego, na które składają się odpowiednie świadczenia dla bezrobotnych ${ }^{30}$.

Zakładano osiągnięcie dzięki nim do 2010 r. ogólnej stopy zatrudnienia w wysokości 70\%, dla kobiet - 60\%, a dla osób starszych - 50\%.

Kolejne założenia dotyczące pełnego zatrudnienia, poprawy jakości i produktywności pracy oraz wzmacniania spójności społecznej i integracji stały się przedmiotem dodatkowych wytycznych, dołączonych do wcześniejszych przy okazji rozszerzenia UE o kolejne kraje w 2004 r. I choć z perspektywy ponad 3 lat od zakończenia programu można stwierdzić, że wytyczne te nie zostały w pełni zrealizowane, to jednak udało się zainteresować rządy krajów członkowskich oraz wprowadzić w życie pewne elementy elastycznego modelu zatrudniania, będące próbą ograniczania bezrobocia, a także ideę uczenia się do końca życia czy też zdobywania nowych kwalifikacji, niezależnie od wieku.

W czerwcu 2013 r. zostały zaprezentowane kolejne unijne priorytety, których celem było rozwiązanie najbardziej palących problemów europejskiego rynku pracy. Efektem prac Komisji Europejskiej było ustalenie najważniejszych przyczyn

\footnotetext{
${ }_{28}$ M. Arczewska, Uwarunkowania i możliwości wprowadzenia w Polsce polityki flexicurity jako koncepcji poszukiwania równowagi między elastycznościa rynku pracy, a bezpieczeństwem socjalnym osób zatrudnionych i bezrobotnych, w: Elastyczne formy pracy. Szanse i zagrożenia, red. C. Sadowska-Snarska, Wydawnictwo Wyższej Szkoły Ekonomicznej w Białymstoku, Białystok 2008, s. 76-78.

${ }^{29}$ Ibidem.

${ }^{30}$ Wspólne zasady wdrażania modelu flexicurity, komunikat Komisji do Parlamentu Europejskiego, Rady, Europejskiego Komitetu Ekonomiczno-Społecznego i Komitetu Regionów, http://www.mpips.gov. pl/userfiles/File/flexi_komunikat_ue.pdf [dostęp 4.03.2014].
} 
bezrobocia wśród młodzieży oraz powiązanie wcześniej ustalonych priorytetów z podejmowanymi inicjatywami.

Do najważniejszych przyczyn bezrobocia wymienionych przez Komisję zaliczono:

- przedwczesne kończenie nauki bez kwalifikacji,

- brak odpowiednich umiejętności i doświadczenia zawodowego,

- niepewne formy zatrudnienia, a następnie okresy bezrobocia,

- ograniczone możliwości szkoleń,

- niewystarczające/niewłaściwe programy rynku pracy, które nie sprzyjają aktywności i ${ }^{31}$.

Przykładami tzw. flagowych inicjatyw podejmowanych w tym zakresie są:

- „Młodzi w ruchu” - ułatwiająca przechodzenie z okresu nauki do zatrudnienia,

- „Cyfrowa agenda dla Europy” - mająca przyspieszyć rozwój szybkiego Internetu dla gospodarstw domowych i firm,

- „Innowacyjna Unia” - sprzyjająca realizacji pionierskich pomysłów, co w konsekwencji zwiększyłoby liczbę powstających produktów i usług, a co się z tym wiążę nowych miejsc pracy, co warto podkreślić, głównie dla młodych ludzi.

Od początku kryzysu UE proponuje także instrumenty, które z założenia powinny pomóc nowej generacji w wejściu na rynek pracy, jak:

- Program na rzecz nowych umiejętności i zatrudnienia z 2010 r.,

- Program działań na rzecz zatrudnienia młodzieży z 2013 r. - przygotowany przez Europejską Konfederację Związków Zawodowych (ETUC) i BusinessEurope, według najlepszych praktyk rządów i instytucji lokalnych,

- „Szanse dla młodzieży” z 2010 r., który zachęca do odbywania szkoleń w trakcie pracy, staży czy wolontariatu,

- Inicjatywa na rzecz zatrudnienia młodzieży (Youth Employment Initiative - YEI) przeznaczona głównie do walki z bezrobociem.

Głównym instrumentem wspierającym działania podejmowane w ramach Europejskiej strategii zatrudnienia jest Europejski Fundusz Społeczny. Sytuację na rynku pracy ocenia corocznie Rada Europejska na podstawie raportu o zatrudnieniu, przygotowywanym przez Komisję Europejską. Opiera on się na raportach częściowych, pochodzących ze wszystkich krajów członkowskich. Wcześniej, na podstawie

${ }^{31}$ Komunikat Komisji do Parlamentu Europejskiego, Rady, Komitetu Ekonomiczno-Społecznego oraz Komitetu Regionów z dnia 20 grudnia 2011 r. Inicjatywa „Szanse dla młodzieży”, http://europa.eu/legislation_summaries/employment_and_social_policy/community_employment_policies/em0054_pl.htm [dostęp 4.04.2014]. 
wytycznych, każde państwo musi opracować własny plan działań na rzecz wzrostu zatrudnienia ${ }^{32}$.

W Polsce dokumentem realizującym te strategie jest Narodowy plan rozwoju na lata 2007-2013, który w ramach programu horyzontalnego Rozwój zasobów ludzkich i kapitału społecznego wyróżnia poszczególne programy operacyjne oraz jednostki nimi zarządzające ${ }^{33}$. Schemat podejmowanych działań został zaprezentowany w tabeli 2 .

Tabela 2. Układ programów operacyjnych w ramach NPR 2007-2013 - Rozwój zasobów ludzkich i kapitału społecznego

\begin{tabular}{|c|c|}
\hline Program operacyjny & Instytucja zarządzająca \\
\hline Wykształcenie i kompetencje & minister właściwy ds. oświaty i wychowania \\
\hline Zatrudnienie i integracja społeczna & minister właściwy ds. pracy \\
\hline Społeczeństwo obywatelskie & minister właściwy ds. zabezpieczenia społecznego \\
\hline
\end{tabular}

Źródło: Narodowy plan rozwoju 2007-2013, http://www.funduszestrukturalne.gov.pl/informator/npr2/ [dostęp 4.04.2014].

Ponadto, w Narodowym planie rozwoju każdy z wyżej wymienionych programów operacyjnych scharakteryzowany jest według celów, priorytetów operacyjnych oraz spodziewanych efektów jego realizacji.

\section{Założenia polityki edukacyjnej - szkolnictwo wyższe}

W ramach przyjętej w połowie 2013 r. przez rząd Strategii rozwoju kapitału ludzkiego 2020 jednym z podstawowych obszarów interwencji jest wspieranie uczelni wyższych w dostosowywaniu ofert szkoleniowych do aktualnych potrzeb rynku pracy. Odbywa się ono przez:

- Zachęcanie uczelni do wykorzystywania funkcjonujących przepisów prawa zwiększających możliwość samodzielnego, elastycznego konstruowania programów kształcenia. Należy dodać, że uczelnie już uzyskały możliwość dowolnego alo-

\footnotetext{
32 J.M. Szaban, op.cit., s. 66.

33 Narodowy plan rozwoju 2007-2013, dokument przyjęty przez Radę Ministrów, http://www.funduszestrukturalne.gov.pl/informator/npr2/ [dostęp 4.04.2014].
} 
kowania zasobów w zależności od potrzeb przyszłych studentów i rynku pracy na podstawie efektów kształcenia ${ }^{34}$.

- Zróżnicowanie misji i ofert programowych uczelni w Polsce przez stymulowanie powstawania i rozwoju programów kształcenia o wyraźnie odmiennym profilu - praktycznym i akademickim. Ma to na celu wykształcenie silnego sektora studiów wyższych o profilu praktycznym, podniesienie i egzekwowanie standardów na studiach o profilu akademickim oraz lepsze dostosowanie oferty programowej polskich uczelni do zainteresowań studentów oraz rzeczywistych potrzeb społeczno-gospodarczych. Dlatego podjęte zostały prace nad przygotowaniem zmiany przepisów prawa zmierzających do podziału uczelni na uczelnie zawodowe (odpowiadające wymogom rynku pracy) oraz uczelnie badawcze (koncentrujące się na prowadzeniu badań naukowych i realizujące powiązane z nimi programy kształcenia).

- Zwiększenie liczby absolwentów na wybranych kierunkach studiów (głównie informatycznych i technicznych), jako odpowiedź na zapotrzebowanie na specjalistów z zakresu ICT oraz rosnące znaczenie podstawowych kompetencji teleinformatycznych w innych zawodach i specjalizacjach ${ }^{35}$. Efektem zmian będzie zmniejszenie luki kompetencyjnej istniejącej w tym zakresie na polskim rynku pracy, co następnie pozytywnie wpłynie na rozwój gospodarki. Konieczna jest także ewaluacja oraz kontynuowanie programu tzw. kierunków zamawianych przez Ministerstwo Nauki i Szkolnictwa Wyższego.

Oprócz założeń programowych MPiPS, należy wspomnieć także o rozwiązaniach wynikających z uczestnictwa Polski w procesie bolońskim. Priorytetowe cele stawiane przed każdym z państw koncentrujące się na wspieraniu młodych ludzi na rynku pracy to m.in.:

- uznanie uczenia się przez całe życie za integralną część procesu kształcenia, ze szczególnym naciskiem na zdobywanie kwalifikacji, pozyskiwanie nowych kompetencji oraz promowanie elastycznych ścieżek rozwoju osobistego,

- dostosowanie systemu szkolnictwa wyższego do wymogów zgłaszanych przez rynek pracy, tak by zwiększyć możliwości zatrudnienia wśród obecnych oraz przyszłych studentów i absolwentów,

- łączenie działalności edukacyjnej oraz badawczej w celu zwiększenia kreatywności oraz innowacyjności społeczeństwa,

34 Strategia rozwoju kapitału ludzkiego 2020, Ministerstwo Pracy i Polityki Społecznej, http://www. mpips.gov.pl/praca/strategie-i-dokumenty-programowe/strategia-rozwoju-kapitalu-ludzkiego-srkl---projekt-z-31072012-r/ [dostęp 20.03.2014].

${ }^{35}$ ICT (ang. Information and Communication Technology) - sektor rynku zajmujący się telekomunikacją i informatyką. 
- otwarcie europejskiego systemu szkolnictwa wyższego na międzynarodową współpracę,

- promowanie mobilności wśród studentów, kadry naukowej oraz pracowników administracyjnych uczelni,

- usprawnienie mechanizmów ułatwiających zbieranie danych z zakresu funkcjonowania uczelni ${ }^{36}$.

Zwiększenie autonomii i elastyczności zarówno władz uczelni, jak i studentów jest podkreślane jako ważny krok w realizowaniu założeń skutecznego dopasowania kształcenia wyższego do potrzeb rynku pracy przez polityki publiczne. Zgodność celów polskiej polityki edukacyjnej oraz rynku pracy z założeniami europejskimi sprawi, że zdobywane kwalifikacje będą bardziej rozpoznawalne na międzynarodowym rynku pracy, co będzie miało także wpływ na skuteczniejszą walkę z bezrobociem.

\section{Zakończenie}

Konsekwencją okresu transformacji były dwa zjawiska - spadek zatrudnienia i pojawienie się w niespotykanej dotąd w Polsce skali bezrobocia. Oba wiązały się z koniecznością dostosowania rozmiarów i struktury zatrudnienia do warunków i wymogów gospodarki rynkowej. Wysokie bezrobocie dotknęło wszystkie kategorie pracowników, w tym także młode pokolenie Polaków. Wobec braku pracy część z nich wyjechała za granicę. Badania pokazują, że Polskę opuszczali często młodzi, najlepiej wykształceni, przedsiębiorczy i najbardziej mobilni pracownicy.

Zarówno prezentowane wyniki badań Bilans Kapitału Ludzkiego z 2013 r., jak i dane Eurostatu pokazują, że młodzi ludzie w całej Unii Europejskiej stanowią grupę defaworyzowaną przez pracodawców, jeśli chodzi o formy zatrudnienia (elastyczne i terminowe umowy o pracę) i oferowane im warunki finansowe. Instytucje unijne i ich podmioty wykonawcze w poszczególnych krajach przygotowują rekomendacje i wytyczne w sprawie działań, które mają na celu włączenie młodych pracowników i pracodawców w bardziej aktywne rozwiązywanie problemów rynku pracy. Dyskusje poświęcone zwalczaniu bezrobocia wśród młodzieży odbywają się także na arenie międzynarodowej.

\footnotetext{
36 Komunikat z konferencji ministrów z krajów UE odpowiedzialnych za edukację, 28-29.04.2009, The Bologna Process 2020 - the European Higher Education Area in the New Decade, http://www.ehea.info/Uploads/Declarations/Leuven_Louvain-la-Neuve_Communiqu\%C3\%A9_April_2009.pdf [dostęp 4.04.2014].
} 
Warto podkreślić to, że wynikiem programowania perspektywy finansowej UE na lata 2014-2020 są cele strategiczne koncentrujące się zarówno na wspieraniu zatrudnienia i mobilności pracowników (cel 8), jak i inwestowaniu w edukację, umiejętności oraz uczenie się przez całe życie (cel 10), opierające się na zdecydowanej poprawie podstawowych wskaźników zatrudnienia i aktywności ekonomicznej ludzkości, $\mathrm{w}$ tym wspomnianej grupie $\mathrm{NEET}^{37}$.

Podsumowując, należy podkreślić fakt, że najważniejszym celem polityk publicznych względem młodych ludzi jest dostosowanie istniejącej oferty edukacyjnej do potrzeb szybko zmieniającego się rynku pracy. Trzeba przy tym pamiętać, że skutki proponowanych rozwiązań poznamy dopiero za kilka lub kilkanaście lat. Warto zatem wcześniej dobrze się do nich przygotować, chociażby przez dokładne rozpoznanie oczekiwań najważniejszych stron zaangażowanych w procesy zmian.

\section{Labour market and educational system. Outline of the key issues}

In Poland and other European Union member states, young people are disfavoured by employers in the labour market. This applies to the forms of employment (flexible and fixed-term contracts) and its financial conditions. In 2013, the unemployment rate among economically active population under the age of 25 in the EU was $23.1 \%$, while in Poland it amounted to $27 \%$. The problems of the young people in the labour market include the mismatch of skills sought by employers and the ones mastered by potential employees, the limited number of new jobs, as well as the discriminatory practices of employers towards young people. Young people classified as NEET (not in employment, education, training) generate considerable social costs. In 2010, $16.5 \%$ of individuals in the 18-24 group and $19.7 \%$ in the 2529 group in the EU were classified as NEETs. The EU supported the member states' governments actions regarding young people via the Lisbon Strategy and the Europe 2020 Strategy. The EU also proposed a new model for flexible management of the labour market (the so-called flexicurity) to improve the efficiency of labour markets and to ensure more jobs while fostering social security of workers. In Poland, the Ministry of Labour and Social Policy implemented the government policy as well as the recommendations of the European Commission through the "Youth in the labour market" programme.

37 Umowa partnerska. Prognozowanie nowej perspektywy finansowej 2014-2020, 21 maja 2014, http:// www.mir.gov.pl/aktualnosci/fundusze_europejskie/Documents/Umowa_Partnerstwa_21_05_2014.pdf [dostęp 8.09.2014]. 
Keywords: unemployment, labour market, young employees, public policies

\section{Le marché du travail et le système éducatif}

En Pologne et dans les autres Etats membres de l'Union européenne les jeunes sont joués en défaveur par les employeurs sur le marché du travail. Cela s'applique aux formes d'emploi et conditions financières. En 2013, le taux de chômage parmi la population économiquement active âgée de moins de 25 dans l'UE était de $23,1 \%$, tandis qu'en Pologne - 27\%. Les problèmes des jeunes dans le marché du travail comprennent: l'inadéquation entre les compétences recherchées par les employeurs et celles des employés potentiels, le nombre limité de nouveaux emplois et les pratiques discriminatoires des employeurs à l'égard des jeunes. Les jeunes classés comme NEET (not in education, employment, or training, ni étudiant, ni employé, ni stagiaire) génèrent des coûts sociaux considérables. En 2010, ils étaient 16,5\% dans le groupe des 18 à 24 ans et 19,7\% dans le groupe des 25 à 29 ans dans l'UE. L'Union soutient les gouvernements nationaux dans leurs efforts pour améliorer la situation des jeunes, tant au sein de la stratégie de Lisbonne et de la stratégie Europe 2020. L'UE a également proposé un nouveau modèle de gestion du travail et de l'emploi - la fléxicurité - pour améliorer l'efficacité des marchés du travail dans l'UE et d'assurer plus d'emplois tout en favorisant la sécurité sociale des travailleurs. En Pologne, le ministère du Travail et de la Politique sociale a proposé un nouveau programme »Les jeunes sur le marché du travail«, qui est à la fois la mise en œuvre des politiques gouvernementales, ainsi que des recommandations de la Commission européenne. En outre, le ministère soutient le fonctionnement des services publics de l'emploi, des bureaux de carrière universitaires ou des employeurs.

Mots-clés: le chômage, le marché du travail, les jeunes travailleurs, les politiques publiques

\section{Рынок труда и система образования. Ключевые вопросы}

В Польше и других государствах-членах Европейского союза молодые люди обездолены работодателями на рынке труда. Это относится как к формам занятости (гибкие и фиксированные сроки контрактов), так и к финансовым условиям. В 2013 году уровень безработицы среди экономически активного 
населения в возрасте до 25 лет в ЕС составил 23,1\%, а в Польше $27 \%$. Проблема молодежи на рынке труда состоит в несоответствии между ожидаемыми работодателями и обладаемыми потенциальными сотрудниками умениями, в ограниченном количестве новых рабочих мест, а также в дискриминационной практике работодателей в отношении молодежи. Молодые люди, классифицированные как NEET (нигде не работающие, не получающие образования, не проходящие профессиональную подготовку), являются источником значительных социальных издержек. В 2010 году в ЕС 16,5\% людей в возрастной группе от 18 до 24 лет и 19,7\% в группе от 25 до 29 лет были классифицированы как NEET. EC поддержал действия правительств государств-членов в отношении молодых людей в Лиссабонской стратегии и стратегии Европа 2020. ЕС также предложил новую модель для гибкого управления на рынке труда (так называемой flexicurity) с целью повышения эффективности рынков труда и предоставления новых рабочих мест, одновременно обеспечивая социальную защищенность работников. В Польше государственная политика и рекомендации Европейской комиссии осуществляются Министерством труда и социальной политики в рамках программы «Молодежь на рынке труда».

Ключевые слова: безработица, рынок труда, молодые сотрудники, публичные политики 